\title{
ANALISIS KOMUNIKASI PETANI KARET POLA SWADAYA DI KECAMATAN GUNUNG TOAR KABUPATEN KUANTAN SINGINGI
}

\author{
Yuliadi Saputra*, Roza Yulida, Rosnita, Yulia Andriani \\ Jurusan Agribisnis, Fakultas Pertanian, Universitas Riau \\ J1. HR. Subrantas. Km 12.5 Simpang Baru 28293, Pekanbaru \\ *Corresponding author: yuliadi.sp@gmail.com
}

\begin{abstract}
This research aims to analyze the effectiveness of rubber farmer communications through the identification of internal and external characteristics and the communication process reviewed from elements of communication. This research applied a survey method in two villages in Gunung Toar sub-district through an interview to 83 respondents by using purposive sampling method. The analysis of the scale of Likert used to analyze the level of cosmopolitan and external characteristics. Descriptive analysis used to analyse the communication processes reviewed from communication elements. Characteristics of the internal and external rubber farmers are: 99\% of age-productive respondents, $89 \%$ male gender, $42 \%$ high school educated and undergraduated, $77 \%$ have medium land area $(0.5-2 \mathrm{ha}), 71 \%$ experienced farming between 11-20 years, 58\% have Between 3-4 people, the level of cosmopolitan respondents judged ineffective. The intensity of the respondents' rubber counseling is quite effective, the accuracy of the counseling channel is quite effective, and information source is quite effective. The communication process consists of extension, farmer group core management, touke, trader and others as source of information. Message in the form of information about farming in the upstream, cultivation, downstream and supporting subsystems. Media is in the form of meetings, WhatsApps, cellphones, brochures, and rubber farmers as communicants. Feedback in the form of agree, ready to try and rejection feedback. The physical environment is in the village office, sub-district office and in the direct field and counseling is held once a week.
\end{abstract}

Keywords: rubber, internal characteristics, external characteristics, communication elements, communication process

\begin{abstract}
Abstrak: Penelitian ini bertujuan untuk menganalisis komunikasi petani karet melalui identifikasi karakteristik internal dan karakteristik eksternal serta proses komunikasi yang ditinjau dari unsur-unsur komunikasi. Penelitian ini menggunakan metode survei pada dua desa di Kecamatan Gunung Toar melaui wawancara responden yang berjumlah 83 responden menggunakan kuesioner. Pengambilan sampel dilakukan dengan metode purposive sampling. Alat analisis yang digunakan yaitu analisis skala likert yang digunakan untuk menganalisis tingkat kosmopolitan dan karakteristik eksternal. Analisis deskriptif yang digunakan untuk menganalisis proses komunikasi yang ditinjau dari unsur-unsur komunikasi. Karakteristik internal dan eksternal petani karet yaitu: $99 \%$ responden berusia produktif, $89 \%$ berjenis kelamin laki-laki, $42 \%$ berpendidikan SMA dan S1, 77\% memiliki luas lahan sedang $(0,5-2 \mathrm{ha}), 71 \%$ berpengalaman usahatani antara 11-20 tahun, 58\% memiliki tanggungan antara 3-4 orang, tingkat kosmopolitan responden dinilai tidak efektif. Intensitas penyuluhan karet responden cukup efektif, ketepatan saluran penyuluhan cukup efektif, sumber informasi cukup efektif. Proses komunikasi yang terjadi yaitu: penyuluh, pengurus inti kelompok tani, touke, pedagang dan lainnya sebagai sumber informasi. Pesan berupa informasi tentang usahatani pada subsistem hulu, budidaya, hilir dan penunjang.
\end{abstract}


Media berupa pertemuan, whatsapp, handphone dan brosur, petani karet sebagai komunikan. Feedback berupa feedback setuju, siap mencoba dan penolakan. Lingkungan fisik yaitu di kantor desa, kantor camat dan di lapangan langsung serta penyuluhan dilaksanakan satu kali seminggu.

Kata kunci: karet, karakteristik internal, karakteristik eksternal, unsur-unsur komunikasi, proses komunikasi

\section{PENDAHULUAN}

Indonesia adalah negara agraris di mana sebagian besar wilayahnya digunakan untuk sektor pertanian. Mayoritas masyarakat Indonesia hidup dari hasil bercocok tanam atau bertani sehingga pertanian merupakan sektor penting dalam meningkatkan kesejahteraan kehidupan masyarakat Indonesia. Subsektor perkebunan merupakan salah satu subsektor sektor pertanian yang dapat meningkatkan kemakmuran dan kesejahteraan rakyat, meningkatkan penerimaan devisa negara melalui ekspor, menyediakan lapangan kerja, memenuhi kebutuhan konsumsi dalam negeri, bahan baku industri dalam negeri, memperoleh nilai tambah dan daya saing serta optimalisasi pengelolaan sumber daya alam. Subsektor perkebunan mencakup semua jenis kegiatan tanaman perkebunan yang diusahakan baik oleh rakyat maupun perusahaan perkebunan.

Salah satu komoditi perkebunan yang menyumbang devisa bagi negara Indonesia adalah perkebunan karet. Sudah sejak lama penduduk indonesia berusahatani tanaman karet, sehingga cukup banyak petani saat ini yang menjadikan usahatani tanaman karet sebagai mata pencaharian utamanya. Banyaknya petani indonesia yang berusahatani tanaman karet dengan produktivitas yang cukup tinggi menyebabkan indonesia memiliki total produksi karet yang cukup besar. Menurut data ANRPC (2018) Indonesia menjadi produsen karet terbesar kedua dunia setelah Thailand yaitu sekitar 3,774 juta ton pada tahun 2018 . Kementerian Pertanian mengungkapkan per september 2018 sektor perkebunan karet mampu menyumbang devisa dari perolehan ekspor senilai 328 juta dolar AS dengan volume sebanyak 3,4 juta ton. Badan Pusat Statistik (BPS) Provinsi Riau tahun 2018 mengatakan bahwa Provinsi Riau memiliki luas areal sebesar 8.702.366 ha dimana sekitar 487.952 ha merupakan areal perkebunan karet atau sekitar 5,6 persen dari total luas areal
Provinsi Riau. Luas areal perkebunan karet tersebut seharusnya dapat memberikan produksi yang lebih besar dengan meningkatkan produktivitas produksinya. Tersedianya lahan yang luas memberikan peluang untuk menghasilkan karet alami yang lebih besar lagi dengan menambah areal perkebunan karet (Harahap dan Segoro, 2018).

Sebagian besar petani karet Indonesia berusahatani tanaman karet dengan teknikteknik lama yang diajarkan secara turun temurun oleh keluarganya. Petani yang memiliki pengetahuan baik terhadap budidaya tanaman karet akan mengajarkan teknik yang benar, namun petani yang tidak memiliki pengetahuan yang baik akan mengajarkan teknik yang salah terhadap keluarganya. Teknik budidaya yang salah tersebut menyebabkan produktivitas karet rendah, kualitas karet buruk dan harga karet hancur. Hingga saat ini hanya sebagian kecil petani saja yang mengetahui budidaya tanaman karet yang baik dan benar, sehingga dibutuhkan orang-orang yang terampil dan memiliki pengetahuan serta pengalaman yang baik tentang budidaya tanaman karet agar dapat bertukar informasi dan pengetahuan kepada petani-petani yang belum banyak memiliki pengetahuan tersebut. Tidak banyak petani yang memiliki pengetahuan dan pengalaman yang baik seputar usahatani karet memiliki sifat acuh atau peduli terhadap kondisi petani disekitarnya. Semua permasalahan tersebut dapat diatasi jika terdapat orang yang mau berbagi pengetahuan dan pengalamannya dengan sabar dan ikhlas. Sabar dan ikhlas seseorang akan berbuah kesuksesan, sukses dalam bersosial dan masyarakat maupun sukses dalam berusaha dan berkarir. Penelitian ini bertujuan untuk menganalisis karakteristik internal dan eksternal petani karet pola swadaya serta melihat proses komunikasi melalui identifikasi unsur-unsur komunikasi di Kecamatan Gunung Toar Kabupaten Kuantan Singingi. Hasil penelitan ini diharapkan bisa menjadi masukan 
bagi pemerintah dan petani dalam mengembangkan penyuluhan petani perkebunan karet di Kecamatan Gunung Toar Kabupaten Kuantan Singingi dan menjadikan sebagai potensi yang sangat membantu petani kedepannya.

\section{METODE PENELITIAN}

Penelitian ini dilaksanakan di dua desa pada Kecamatan Gunung Toar Kabupaten Kuantan Singingi. Gunung Toar dipilih karena merupakan salah satu Kecamatan berpotensi pada sektor perkebunan karet di Kabupaten Kuantan Singingi. Kecamatan Gunung Toar dipilih secara sengaja sebagai lokasi penelitian karena memiliki potensi pada jumlah petani, luas lahan dan produksinya. Gunung toar merupakan satu-satunya kecamatan yang memiliki tiga GAPOKTAN pemasaran di Kabupaten Kuantan Singingi. Desa yang menjadi objek penelitian ini merupakan desa yang memiliki kelompok tani aktif lima tahun terakhir yaitu Desa Lubuk Terentang dan Desa Gunung yang dipilih berdasarkan saran dari penyuluh perkebunan karet Gunung Toar. Penelitian ini melihat efektivitas komunikasi penyuluhan terhadap petani karet, dilaksanakan selama enam bulan yaitu dimulai bulan November 2018 sampai Juli 2019.

Metode yang digununakan pada penelitian ini adalah metode survei melalui wawancara langsung dan pengisian kuesioner untuk responden. Populasi petani karet pola swadaya di Kecamatan Gunung Toar khususnya di Desa Lubuk Terentang dan Desa Gunung berjumlah 504 petani karet pola swadaya. Teknik pengambilan sampel penelitian ini dengan cara sengaja (purposive sampling) dengan kriteria petani karet yang memiliki status lahan kepemilikan sendiri, mengelola sendiri, tergabung kedalam kelompok tani dan telah mengikuti penyuluhan. Jumlah sampel yang diambil untuk mewakili populasi sebanyak 83 petani dari total 504 populasi petani karet pola swadaya pada dua desa yaitu di Desa Lubuk Terentang dan Desa Gunung di Kecamatan Gunung Toar. Sebaran sampel yang diambil disesuaikan secara proposional berdasarkan keaktifan.

Jenis data yang digunakan dalam penelitian ini adalah data primer dan data sekunder. Data primer terdiri dari identitas responden yang dikumpulkan melalui wawancara dengan menggunakan alat pengumpulan data berupa kuesioner. Data sekunder didapatkan dari analisis dokumendokumen dan pustaka yang berasal dari berbagai sumber yang berhubungan dengan tujuan penelitian. Seperti jurnal, buku-buku, data-data statistik baik dari BPS, dinas perkebunan maupun dari dinas-dinas terkait lainnya. Data yang dikumpulkan melalui wawancara dengan bantuan kuesioner diolah dan dianalisis dengan menggunakan Analisis Skala Likert dan Analisis Deskriptif. Menurut Kinnear (1988) dalam Husein (2011) skala Likert ini berhubungan dengan pernyataan tentang sikap seseorang terhadap sesuatu, misalnya setuju-tidak setuju, senang-tidak senang dan baik-tidak baik.

Metode analisis Skala Likert digunakan untuk menjawab tujuan penelitian yaitu mengetahui karakteristik internal dan eksternal petani karet pola swadaya di Kecamatan Gunung Toar Kabupaten Kuantan Singingi. Indikator yang menggunakan analisis skala likert yaitu kosmopolitan, intensitas penyuluhan, ketepatan saluran dan sumber informasi. Analisis deskriptif digunakan untuk menjawab tujuan penelitian mendeskripsikan unsur-unsur komunikasi dan menjelaskan tujuan dari krakteristik internal dan eksternal. Menurut Sugiyono (2005) menyatakan bahwa metode deskriptif adalah suatu metode yang digunakan untuk menggambarkan atau menganalisis suatu hasil penelitian tetapi tidak digunakan untuk membuat kesimpulan yang lebih luas. Nilai skala jawaban tertutup dari responden dibuat peneliti dalam bentuk pernyataan positif (jawaban yang diharapkan) diberi nilai 3 hingga pernyataan negatif (jawaban yang tidak diharapkan) diberi nilai 1 seperti dibuat dalam tabel 1 berikut ini :

Tabel 1. Nilai Skala Jawaban yang Diberikan Responden (Pernyataan Positif)

\begin{tabular}{clc}
\hline No & Kategori & Skala Nilai \\
\hline 1 & Efektif & 3 \\
2 & Cukup efektif & 2 \\
3 & Tidak efektif & 1 \\
\hline
\end{tabular}

Sumber: Kinner dalam Husein, 2011

Jumlah pertanyaan untuk mengetahui tingkat karakteristik petani karet pola swadaya di Kecamatan Gunung Toar Kabupaten 
Kuantan Singingi secara keseluruhan yaitu dua puluh pertanyaan, diantaranya delapan pertanyaan karakteristik internal, enam pertanyaan karakteristik eksternal dan enam pertanyaan unsur-unsur komunikasi. Nilai tertinggi diberikan skor (3), dan nilai terendah (1), sehingga didapat perhitungan kisarannya sebagai berikut:

Nilai maksimum $=83 \times 3 / 83=3$

Nilai minimum $=83 \times 1 / 83=1$

Besar kisarannya $=(3-1) / 3-0,01=0,6567$

Total nilai pokok skala yang dikelompokkan menjadi tiga kategori dan persepsi dapat dihitung dengan menggunakan rumus:

Nilai Variabel $=$ Jumlah Pertanyaan $\times$ Nilai Skala / Jumlah Pertanyaan

Kategori Variabel $=($ Nilai Maksimum - Nilai Minimum) / Jumlah Kategori

Berdasarkan nilai yang didapat dari perhitungan diatas maka untuk mengetahui tingkat efektivitas karakteristik dapat melihat dari kategori nilai skala berikut:

Tabel 2. Skala Penilaian Terhadap Efektivitas Karakteristik Petani Karet Pola Swadaya

\begin{tabular}{llc}
\hline \multirow{2}{*}{ No } & \multicolumn{2}{c}{ Skor Tingkat Efektivitas Karakteristik } \\
\cline { 2 - 2 } Kategori & Kategori nilai skala \\
\hline 1 Efektif & $2,67-3,00$ \\
2 & Cukup Efektif & $1,67-2,66$ \\
3 & Tidak Efektif & $1,00-1,66$ \\
\hline
\end{tabular}

Sumber: Kinner dalam Husein, 2011

\section{HASIL DAN PEMBAHASAN}

\section{Karakteristik Internal Petani}

Karakteristik internal dan karakteristik eksternal dalam komunikasi petani karet dapat dilakukan dengan cara memberikan pertanyaan yang sama kepada sejumlah petani karet pola swadaya yang berada di Kecamatan Gunung Toar, Kabupaten Kuantan Singingi. Dimensi dan variabel karakteristik internal dan karakteristik eksternal disajikan pada Tabel 3 berikut ini.

\section{Umur}

Umur merupakan salah satu faktor penting dalam usahatani tanaman karet. Tingkat kemampuan fisik, daya ingat, mental dan motivasi petani dalam mengelola usahatani tanaman karet sangat dipengaruhi umur. Simanjuntak (2016), menyatakan bahwa angkatan kerja digolongkan produktif apabila umurnya berkisar antara 15-55 tahun. Penduduk yang berumur 0-14 tahun dan berumur lanjut (> 55 tahun) termasuk dalam kategori tidak produktif dan kurang layak untuk bekerja karena produktivitasnya sangat rendah.

Tabel 3. Karakteristik Responden Menurut Usia

\begin{tabular}{|c|c|c|c|}
\hline No & Umur (Tahun) & Jiwa (orang) & $\begin{array}{c}\text { Persentase } \\
(\%)\end{array}$ \\
\hline \multicolumn{4}{|c|}{$1 \begin{array}{l}\text { Belum produktif } \\
\text { (umur 0-14) }\end{array}$} \\
\hline 2 & $\begin{array}{l}\text { Produktif } \\
\text { (umur 15-64) }\end{array}$ & 82 & 99 \\
\hline 3 & $\begin{array}{l}\text { Tidak produktif } \\
\text { (umur 65) }\end{array}$ & 1 & 1 \\
\hline & Total & 83 & 100 \\
\hline
\end{tabular}

Sumber: Data diolah, 2019

Tabel 3 menggambarkan bahwa usia petani karet swadaya di Kecamatan Gunung Toar yang menjadi responden penelitian ini mayoritas berusia produktif antara 15 tahun sampai dengan 64 tahun dengan persentase 99\% dari total responden, sedangkan petani yang berada pada usia tidak produktif atau berusia 65 tahun hanya berjumlah satu orang dengan persentase $1 \%$. Usia produktif biasanya menunjukkan kekuatan dan kemampuan fisik ataupun pikiran yang baik, sehingga usia produktif sangat potensial dalam memaksimalkan peran sertanya terhadap kegiatan usahatani karet.

\section{Pendidikan}

Pendidikan merupakan salah satu faktor yang dapat mempengaruhi seseorang dalam berfikir dan mengambil keputusan. Pendidikan juga dapat mengubah cara pandang seseorang terhadap sesuatu dimana yang akan datang. Mubarak et al. (2007) mengatakan semakin tinggi pendidikan seseorang semakin mudah pula mereka menerima informasi, dan pada akhirnya makin banyak pula pengetahuan yang dimilikinya. Apabila seseorang tingkat pendidikannya rendah, akan menghambat perkembangan sikap seseorang terhadap penerimaan, informasi dan nilai-nilai baru yang baru diperkenalkan. Berikut ditampilkan 
karakteristik responden penelitian ini berdasarkan tingkat pendidikan.

Tabel 4. Karakteristik Responden Menurut Tingkat Pendidikan

\begin{tabular}{clcc}
\hline No Pendidikan & $\begin{array}{c}\text { Jiwa } \\
\text { (orang) }\end{array}$ & $\begin{array}{c}\text { Persentase } \\
(\%)\end{array}$ \\
\hline 1 & SD \& Tidak SD & 26 & 31 \\
2 & SMP & 22 & 27 \\
3 & SMA \& S1 & 35 & 42 \\
\hline \multicolumn{2}{c}{ Total } & 83 & 100 \\
\hline
\end{tabular}

Sumber: Data diolah, 2019

Tabel 4 menggambarkan bahwa tingkat pendidikan responden petani karet pola swadaya di Kecamatan Gunung Toar sebagian besar memiliki tingkat pendidikan SD dan tidak SD yaitu sebanyak 33 responden dengan persentase $40 \%$ dari total responden. Tingkat pendidikan SMA dan S1 sebanyak 33 responden atau $40 \%$ dari total responden, lulusan tingkat SMP sebanyak 17 responden atau $20 \%$ dari total responden.

Tingkat pendidikan yang telah diukur tersebut didapatkan petani yang berpendidikan rendah cenderung untuk tidak mengambil peran aktif dalam kelompok. Dominasi dari pengurus baik kelompok tani, gabungan kelompok tani maupun koperasi adalah lulusan SMA dan S1. Beberapa petani dengan lulusan SMA tidak dapat melanjutkan pendidikannya dikarenakan keterbatasan ekonomi. Bahkan beberapa diantara petani yang menjadi responden dengan tingkat lulusan SMA memiliki pengetahuan dan pengalaman lebih banyak bila dibandingkan dengan lulusan S1. Hal ini karena motivasi untuk mencaritahu lebih banyak tentang usahatani tanaman karet yang didapatkan dari tanggung jawab yang diemban, seperti sebagai ketua kelompok tani atau GAPOKTAN, sekretaris kelompok atau GAPOKTAN ataupun kepala desa. Tidak hanya tanggung jawab yang diemban, namun faktor kesempatan yang didapatkan juga mempengaruhi pengetahuan dan motivasi petani dalam berusahatani. Seperti kegiatan pelatihan yang diadakan oleh dinas terkait seputar tanaman karet ataupun dari penyuluhan yang dilakukan penyuluh baik secara langsung maupun tidak langsung.

\section{Luas Lahan}

Menurut Budiyanto (2014) lahan merupakan suatu bentang tanah yang dimanfaatkan dan merupakan modal dasar dalam kegiatan budidaya tanaman pertanian. Apabila luas lahan meningkat maka pendapatan petani akan meningkat, demikian juga sebaliknya, sehingga hubungan antara luas lahan dengan pendapatan petani merupakan hubungan yang positif. Berikut akan ditampilkan luas lahan yang dimiliki responden.

Tabel 5. Karakteristik Responden Menurut Luas Lahan

\begin{tabular}{clcc}
\hline No & \multicolumn{1}{c}{ Luas Lahan } & $\begin{array}{c}\text { Jiwa } \\
\text { (orang) }\end{array}$ & $\begin{array}{c}\text { Persentase } \\
(\%)\end{array}$ \\
\hline 1 & $\begin{array}{l}\text { Petani Luas Lahan } \\
\text { Sempit }(<0,5)\end{array}$ & 8 & 10 \\
2 & $\begin{array}{l}\text { Petani Luas Lahan } \\
\text { Sedang }(0,5-2)\end{array}$ \\
$\begin{array}{l}\text { Petani Luas Lahan } \\
\text { Luas (>2) }\end{array}$ & 11 & 77 \\
\hline \multicolumn{1}{c}{ Total } & Rata-rata & 1,6 ha \\
\hline
\end{tabular}

Sumber: Data diolah, 2019

Tabel 5 menunjukkan bahwa petani karet pola swadaya di Kecamatan Gunung Toar sebagian besar memiliki lahan untuk usahatani tanaman karet dengan luas antara 0,5 ha -2 ha atau termasuk kedalam kategori luas lahan sedang yaitu sebanyak 64 responden dengan persentase $77 \%$ dari total responden. Petani karet dengan luas lahan kecil dari 0,5 ha atau termasuk kategori petani dengan luas lahan sempit sebanyak 8 responden atau 10 persen dari total responden. Petani dengan luas lahan besar dari dua ha atau termasuk petani dengan luas lahan luas sebanyak 11 responden atau 13 persen dari total responden, sehingga rata-rata luas lahan milik responden sebesar 1,6 ha. Status seluruh luas lahan tersebut merupakan kepemilikan sendiri dan digarap sendiri.

\section{Pengalaman Usahatani}

Pengalaman adalah cara bagi seseorang untuk memperoleh pengetahuan yang paling sulit untuk dilupakan, baik pengalaman itu didapatkan sendiri maupun bersama orang lain. Pengalaman dalam usahatani merupakan faktor yang dapat mempengaruhi keterampilan dan kecekatan petani mengelola permasalahan didalam usahataninya. Menurut Mardani (2017) lamanya pengalaman berusahatani ini mempengaruhi tingkat kemampuan petani dalam mengelola usahataninya secara baik. Kemampuan usahatani ini juga dipengaruhi oleh beberbagai faktor seperti sarana yang 
lengkap, rasa keingintahuan dan kemampuan menyadari akan suatu hal. Karakteristik responden beradasarkan pengalaman usahatani dapat dilihat pada Tabel 6.

Tabel 6. Karakteristik Responden Menurut Pengalaman Usahatani

\begin{tabular}{cccc}
\hline No & $\begin{array}{c}\text { Pengalaman } \\
\text { Usahatani (Tahun) }\end{array}$ & $\begin{array}{c}\text { Jiwa } \\
\text { (orang) }\end{array}$ & $\begin{array}{c}\text { Persentase } \\
(\%)\end{array}$ \\
\hline 1 & $1-10$ & 22 & 27 \\
2 & $11-20$ & 59 & 71 \\
3 & $21-37$ & 2 & 2 \\
\hline \multicolumn{3}{c}{ Rata-rata } & 14 Tahun
\end{tabular}

Sumber: Data diolah, 2019

Tabel 6 menggambarkan bahwa petani karet pola swadaya di Kecamatan Gunung Toar sebagian besar memiliki pengalaman berusahatani antara 11-20 tahun yaitu sebanyak 59 responden atau $71 \%$ dari total responden, kemudian petani dengan pengalaman antara 110 tahun sebanyak 22 responden atau $27 \%$ dari total responden, petani dengan pengalaman antara 21-30 tahun sebanyak dua responden atau 2\% dari total responden. Pengalaman usahatani responden terendah yaitu selama empat tahun dan pengalaman usahatani tertinggi selama 37 tahun serta rata-rata pengalaman usahatani karet selama 14 tahun Secara umum petani melakukan usahatani tanaman karet dimulai dari kecil bersama orang tua, hingga sekarang teknik-teknik yang diajarkan orang tua masih diterapkan di lahan masing-masing. Usia yang bertambah dan pengalaman yang meningkat menyebabkan beberapa petani mengadopsi cara-cara berusahatani dari penyuluh atau sumber informasi lainya.

\section{Jumlah Tanggungan Keluarga}

Jumlah tanggungan keluarga adalah jumlah individu baik istri, anak, anggota keluarga besar ataupun orang lain oleh kepala rumah tangga. Jumlah tanggungan keluarga dapat menggambarkan seberapa besar beban atau biaya yang dikeluarkan kepala rumah tangga untuk memenuhi kebutuhan tanggungannya. Semakin banyak jumlah tanggungan seorang kepala keluarga maka akan semakin besar biaya yang dikeluarkan untuk memenuhi kebutuhan keluarganya. Besarnya jumlah tanggungan keluarga juga mempengaruhi inovasi petani dalam mengelola usahataninya. Jumlah anggota keluarga akan mempengaruhi keputusan dalam berusaha. Petani yang memiliki jumlah tanggungan yang besar harus mampu mengambil keputusan yang tepat agar risiko dapat diminimalkan. Menurut Rohi (2008) jumlah tanggungan keluarga memberikan motivasi kepada pemuka pendapat untuk meraih keberhasilan dalam usahataninya dengan cara menerapkan teknologi usahatani yang dianggap dapat memberikan keuntungan lebih tinggi untuk pemenuhan kebutuhan keluarganya. Data jumlah tanggungan keluarga dari responden penelitian berikut ini akan disajikan pada Tabel 7.

Tabel 7. Karakteristik Responden Menurut Jumlah Tanggungan

\begin{tabular}{cccc}
\hline No & Jumlah Tanggungan & $\begin{array}{c}\text { Jiwa } \\
\text { (orang) }\end{array}$ & $\begin{array}{c}\text { Persentase } \\
(\%)\end{array}$ \\
\hline 1 & $1-2$ & 27 & 33 \\
2 & $3-4$ & 48 & 58 \\
3 & 5 & 8 & 10 \\
\hline \multicolumn{3}{c}{ Rata-rata } & 3 Orang \\
\hline
\end{tabular}

Sumber: Data diolah, 2019

Tabel 7 menunjukan bahwa petani karet pola swadaya di Kecamatan Gunung Toar ratarata memilki tanggungan sebanyak tiga orang dan sebagian besar memiliki jumlah tanggungan antara 0-2 orang sebanyak 27 responden atau $33 \%$ dari total responden, jumlah tanggungan antara 3-4 orang sebanyak 88 responden atau $58 \%$ dari total responden, dan responden yang memiliki jumlah tanggungan lima orang sebanyak delapan responden atau 10 persen dari total responden. Berdasarkan data tersebut dapat disimpulkan bahwa motivasi petani untuk memperoleh keberhasilan dalam usahatani dan memenuhi kebutuhan keluarga cukup rendah karena jumlah tanggungan dari anggota keluarga yang ditanggung kepala keluarga masih dalam kategori rendah, seperti yang dikatakan Ahmadi (2007) jumlah tanggungan dapat digolongkan menjadi:

a Tanggungan besar, apabila jumlah tanggungan $\geq$ lima orang.

b Tanggungan kecil, apabila jumlah tanggungan $<$ lima orang. 
Yuliadi S., Roza Y., Rosnita, Yulia A. : Analisis Komunikasi Petani Karet ...

Tabel 8. Karakteristik Responden Menurut Tingkat Kosmopolitan

\begin{tabular}{ccccccc}
\hline No & Kosmopolitan & Skor & Jiwa & $\%$ & Skor & Kategori \\
\hline 1 & Membaca & 1 & 51 & 61 & & \\
& & 2 & 29 & 35 & 1,42 & Tidak Efektif \\
2 & 3 & 3 & 4 & & \\
& Bergaul & 1 & 21 & 25 & & Cukup Efektif \\
3 & & 36 & 43 & 2,06 & \\
& & 3 & 26 & 31 & & Tidak Efektif \\
& Bepergian & 1 & 57 & 69 & & Tidak Efektif \\
\hline
\end{tabular}

Sumber: Data diolah, 2019

\section{Tingkat Kosmopolitan}

Kosmopolitan menurut kamus besar bahasa indonesia (KBBI) yaitu memiliki wawasan yang luas, sehingga kosmopolitan memiliki arti salah satu tolak ukur petani dalam efektivitas berkomunikasi. Kosmopolitan petani dapat dilihat dari keingintahuan yang tinggi terhadap permasalahan-permasalahan yang terjadi baik didalam kelompok tani maupun di dalam budidaya. Semakin tinggi tingkat kosmopolitan petani maka akan semakin banyak bahan diskusi ketika berinteraksi dengan petani lain. Rukka (2003) menyatakan bahwa melalui sifat kosmopolitan, dimungkinkan terjadinya peningkatan wawasan dan belajar di kalangan petani atas keberhasilan orang yang berada di luar daerahnya sehingga petani tersebut dapat terpacu menjadi lebih baik. Petani yang saling bertukar pengalaman dan informasi, baik dengan petani lain maupun peneliti atau penyuluh, akan menambah pengetahuan petani tersebut terhadap hal-hal baru. Kondisi kosmopolitan responden dapat dilihat pada Tabel 8.

Data pada Tabel 8 menggambarkan tingkat kosmopolitan responden yang diukur melalui tiga indikator yaitu membaca buku atau artikel mengenai budidaya karet, bergaul atau berdiskusi bersama penyuluh dan bepergian atau mengikuti pelatihan seputar budidaya tanaman karet. Indikator tertinggi yang dimiliki petani di Kecamatan Gunung Toar adalah bergaul yaitu memasuki kategori cukup efektif dengan skor 2,06. Hal ini terjadi karena adanya sistem pemasaran karet lelang. Sistem pemasaran karet dengan cara lelang dapat menawarkan karet dengan harga yang cukup tinggi. Harga karet yang tinggi tersebut membuat petani-petani karet dari berbagai desa di Kecamatan Gunung Toar tertarik untuk mengikuti sistem pemasaran karet tersebut.

Sistem pemasaran karet dengan cara lelang ini tidak semua petani dapat mengikutinya. Hanya petani yang sudah tergabung kedalam kelompok tani saja yang dapat mengikutinya. Kelompok tani tersebut juga harus bergabung ke dalam GAPOKTAN pemasaran tanaman karet. Melalui kelompok tani tersebut penyuluh hadir untuk memberikan penyuluhan kepada petani mengenai budidaya tanaman karet sambil membantu jalannya sistem perlelangan, karena pada sistem pelelangan karet tersebut penyuluh karet Kecamatan Gunung Toar juga merupakan ketua kelompok sistem pelelangan di Kecamatan Gunung Toar.

Variabel tingkat kosmopolitan petani karet pola swadaya di Kecamatan Gunung Toar termasuk ke dalam kategori tidak efektif dengan skor sebesar 1,61. Artinya, kemampuan petani dalam mencari informasi dapat dikatakan tidak baik. Hal tersebut disebabkan minat membaca petani rendah dan kesempatan petani mengikuti pelatihan-pelatihan seputar budidaya tanaman karet yang rendah.

Indikator selanjutnya adalah membaca dengan skor 1,42 atau berada pada kategori tidak efektif. Hal ini disebabkan rendahnya minat membaca petani karet baik disebabkan faktor internal maupun eksternal. Sutarno (2006) mengelompokkan faktor-faktor yang mempengaruhi minat baca tersebut diantaranya: (1) Rasa ingin tahu masyarakat yang tinggi atas fakta, teori, prinsip, pengetahuan, dan informasi yang mereka butuhkan. (2) Tersedianya bahan bacaan yang menarik, berkualitas, dan beragam di lingkunngan masyarakat itu berada. (3) Tersedianya waktu tertentu yang dapat 
dimafaatkan untuk membaca. (4) Kebutuhan dan rasa ingin tahu masyarakat terhadap informasi yang aktual dan terbaru. (5) Memiliki prinsip bahwa membaca adalah suatu kebutuhan rohani guna memperolah keuntungan ilmu pengetahuan, wawasan dan pengalaman serta kearifan.

Indikator terendah dari kosmopolitan yaitu berpergian dengan skor 1,34 atau pada kategori tidak efektif. Hal ini terjadi karena pelatihan bagi petani banyak dilaksanakan diluar kecamatan. Usaha yang dilakukan untuk menuju lokasi pelatihan membutuhkan biaya lebih, sehingga hanya petani aktif dan berminat tinggi yang dapat mengikutinya. Tingkat bepergian ini sebenarnya memiliki skor tinggi jika dinilai pada tahun lalu atau tahun 2017. Tahun 2017 dan 2016 terdapat sekolah pelatihan bagi petani di dalam kecamatan, dimana pada pelatihan tersebut banyak petani yang termotivasi untuk bergabung kedalam kelompok tani, namun semenjak sekolah pelatihan tersebut dibubarkan banyak petani yang keluar dari kelompok tani, salah satunya adalah petani dari Desa Gunung.

\section{Karakteristik Eksternal}

Karakteristik eksternal merupakan faktor-faktor pendukung yang dapat memengaruhi seseorang dalam memberikan keputusan. Menurut Sumardi et al. (1997) dalam Triyanto (2009) faktor eksternal pembentuk perilaku meliputi segala sesuatu di sekitarnya yang mampu memengaruhi seseorang untuk berperan terhadap suatu kegiatan tertentu, seperti lingkungan sosial masyarakat dan kebijakan pemerintah. Penelitian ini akan membahas keadaan karakteristik eksternal atau faktor pendukung petani dalam berkomunikasi. Karakteristik tersebut diantaranya: intensitas penyuluhan, ketepatan saluran penyuluhan dan sumber informasi.

\section{Intensitas Penyuluhan}

Intensitas penyuluhan merupakan jumlah kegiatan penyuluhan yang diikuti petani yang dilaksaksanakan penyuluh pada suatu waktu dan di suatu tempat. Menurut Permana (2012) penyuluhan dapat diartikan sebagai suatu pendidikan nonformal yang bertujuan untuk membantu masyarakat atau petani mengubah perilakunya dalam hal pengetahuan, keterampilan dan sikap agar mereka dapat memecahkan masalah yang dihadapinya guna mencapai kehidupan yang lebih baik. Intensitas penyuluhan pada penelitian ini bertujuan untuk mengambarkan banyaknya penyuluhan yang dilaksanakan di Kecamatan Gunung Toar Kabupaten Kuantan Singingi, sehingga gambaran yang akan diberikan adalah seberapa sering penyuluh melaksanakan kegiatan penyuluhan. Berikut disajikan Tabel 9 intensitas penyuluhan tanaman karet.

Tabel 9 menunjukkan bahwa secara keseluruhan skor intensitas penyuluhan yang dilakukan penyuluh di Kecamatan Gunung Toar adalah 2,18 atau termasuk ke dalam kategori cukup efektif. Artinya, penyuluh di Kecamatan Gunung Toar cukup sering melaksanakan penyuluhan dan petani memanfaatkan pertemuan tersebut dengan cukup baik. Penyuluh melaksanakan penyuluhan kepada anggota kelompok tani sebanyak satu kali sampai dua kali dalam seminggu. Kegiatan penyuluhan tersebut dimanfaatkan dengan cukup baik oleh anggota kelompok tani. Pemanfaatan kesempatan oleh petani terlihat dari antusias petani dalam memberikan pertanyaan-pertanyaan kepada penyuluh. Ketika pertanyaan-pertanyaan yang hendak diajukan tidak terjawab oleh penyuluh, tidak jarang petani bertanya lagi ketika kegiatan penyuluhan selesai.

Tabel 9. Karakteristik Eksternal, Indikator Intensitas Penyuluhan

\begin{tabular}{|c|c|c|c|c|c|c|}
\hline No & Intensitas Penyuluhan & Skor & Jiwa & $\%$ & Skor & Kategori \\
\hline \multirow[t]{3}{*}{1} & Memanfaatkan Pertemuan & 1 & 16 & 19 & & \\
\hline & & 2 & 48 & 58 & 2,04 & Cukup Efektif \\
\hline & & 3 & 19 & 23 & & \\
\hline \multirow[t]{4}{*}{2} & Intensitas & 1 & 10 & 12 & & \\
\hline & & 2 & 36 & 43 & 2,33 & Cukup Efektif \\
\hline & & 3 & 37 & 45 & & \\
\hline & Rata-rata & & & & 2,18 & Cukup Efektif \\
\hline
\end{tabular}

Sumber: Data diolah, 2019 
Indikator intensitas melaksanakan kegiatan penyuluhan memperoleh skor 2,33. Artinya, penyuluh sudah cukup sering melaksanakan kegiatan penyuluhan kepada petani. Penyuluh melakukan kegiatan penyuluhan termasuk ke dalam kategori sangat tinggi di Desa Lubuk Terentang yaitu penyuluhan dilakukan satu kali dalam seminggu jika kondisi cuaca baik. Apabila cuaca tidak baik maka penyuluhan dilakukan satu kali dalam dua minggu. Desa Gunung dapat dikatakan penyuluh jarang melaksanakan penyuluhan terhadap kelompok tani. Area kerja penyuluh karet di Kecamatan Gunung Toar hanya di dua desa yaitu Desa Gunung dan Desa Lubuk Terentang. Terkadang penyuluh juga melakukan penyuluhan ke luar desa penempatannya namun bersama dengan penyuluh-penyuluh lainnya dalam kegiatan penyuluhan kecamatan.

Hasil wawancara petani di Desa Lubuk Terentang dan Desa Gunung, intensitas mengikuti penyuluhan tertinggi berada pada Desa Lubuk Terentang. Desa Lubuk Terentang memiliki intensitas penyuluhan tertinggi disebabkan petani-petani di Desa Lubuk Terentang merupakan petani yang tergolong cukup aktif dan memiliki antusias yang tinggi terhadap kegiatan penyuluhan. Antusias petani tersebut dapat dilihat pada saat pertemuan yang dihadiri cukup banyak anggota kelompok. Penyuluh melakukan penyuluhan di Desa Gunung tergolong cukup jarang. Penyuluhan terhadap kelompok tani di Desa Gunung dilakukan satu kali dalam sebulan, bahkan pernah tidak dilakukan penyuluhan dalam sebulan. Penyebab penyuluhan jarang dilakukan di Desa Gunung yaitu antusias petani yang rendah ketika diundang dalam kegiatan penyuluhan, sehingga teknik penyuluh terhadap Desa Gunung yaitu mengunjungi langsung ke lapangan atau kebun petani secara langsung.
Indikator memanfaatkan pertemuan memperoleh skor 2,04 atau termasuk ke dalam kategori cukup efektif. Artinya, petani yang melakukan pertemuan dengan penyuluh ataupun mengikuti kegiatan penyuluhan selalu memanfaatkan kesempatan tersebut untuk diskusi-diskusi terkait usahatani tanaman karet dan hal paling sering didiskusikan yaitu mengenai kegiatan pelelangan karet. Informasi yang paling sering dicari petani adalah harga karet dan taoke pelelang berasal darimana saja.

\section{Ketepatan Saluran}

Ketepatan saluran merupakan kesesuaian petani dalam menerima informasi dari kegiatan penyuluhan yang dilaksanakan penyuluh. Terkadang kegiatan penyuluhan yang diberikan penyuluh tidak sesuai dengan keinginan dan kebutuhan petani sehingga petani tidak tertarik untuk mengikuti kegiatan penyuluhan. Cara untuk melihat seberapa efektif kegiatan penyuluhan yang dilakukan penyuluh dapat dilihat pada tabel 10 berikut ini.

Berdasarkan Tabel 10 dapat diketahui bahwa tingkat ketepatan saluran yang digunakan penyuluh secara keseluruhan memperoleh skor 1,90. Artinya, penyampaian informasi penyuluh sudah cukup baik, dilihat dari cara memberikan informasi dan juga jenis informasi yang disampaikan. Penyuluh cukup terampil dalam memilih materi dan menjelaskannya. Hal tersebut disebabkan penyuluh petani karet di Kecamatan Gunung Toar cukup aktif dalam mencari informasi tentang masalah yang sedang dihadapi petani, bahkan penyuluh menelusuri dari satu kebun ke kebun milik petani karet lainnya.

Indikator kemudahan dimengerti alat peraga yang digunakan penyuluh memperoleh skor 1,96 atau termasuk ke dalam kategori cukup efektif. Artinya, alat peraga yang

Tabel 10. Karakteristik Eksternal: Ketepatan Saluran

\begin{tabular}{ccccccc}
\hline No & \multicolumn{1}{c}{ Ketepatan Saluran } & Skor & Jiwa & $\%$ & Skor & Kategori \\
\hline 1 Kemudahan dimengerti alat & 1 & 18 & 22 & 1,96 & Cukup Efektif \\
peraga yang digunakan penyuluh & 2 & 50 & 60 & & \\
& 3 & 15 & 18 & & \\
& Kesesuaian informasi dari & 1 & 15 & 18 & 2,06 & Cukup Efektif \\
penyuluh kepada petani & 2 & 48 & 58 & & \\
\hline Rata-rata & 3 & 20 & 24 & & \\
\hline
\end{tabular}

Sumber: Data diolah, 2019 
digunakan penyuluh sudah cukup efektif dalam memudahkan petani untuk memahami maksud dari meteri penyuluhan yang disampaikan. Penyuluh menggunakan dua metode dalam melakukan penyuluhan yaitu diskusi secara langsung dan menggunakan proyektor sebagai media penyuluhannya tergantung dari materi dan ketersediaan informasi yang dimiliki penyuluh. Penyuluh menggunakan proyektor pada saat penyajiannya, tampilan dari power point yang digunakan penyuluh sudah cukup menarik karena banyak berisi gambar-gambar yang memudahkan petani menangkap informasi yang disampaikan, terutama bagi petani yang tidak bisa membaca.

Indikator kesesuaian informasi dari penyuluh kepada petani memiliki skor 2,06 atau termasuk ke dalam kategori cukup efektif. Artinya, informasi atau materi yang disampaikan penyuluh sudah cukup sesuai dengan keinginan dan kebutuhan petani. Penyuluh selalu menyisipkan informasiinformasi terbaru dan terhangat didalam penyuluhannya. Teknik tersebut menyebabkan petani menjadi tidak bosan untuk memperoleh informasi atau mengikuti kegiatan penyuluhan, walaupun beberapa informasi yang diberikan adalah informasi yang telah disampaikan secara berulang-ulang. Petani yang telah mengikuti begitu banyak kegiatan penyuluhan beranggapan materi yang disampaikan adalah materi yang telah disampaikan berulang-ulang seolah-olah menimbulkan efek bosan, namun hanya beberapa petani saja yang beranggapan seperti itu. Padahal materi tersebut sebenarnya belum didapatkan oleh beberapa petani lainnya.

\section{Sumber Informasi}

Sumber informasi merupakan indikator yang dapat memberikan pilihan bagi petani untuk menentukan sikap dan keputusan dalam bertindak. Sumber informasi bagi petani dalam menetapkan pilihan terhadap usahataninya dapat berupa penyuluh, teman sesama petani, pedagang, internet, pabrik ataupun dari majalah. Semakin banyak jumlah sumber informasi yang dimiliki petani seharusnya dapat meningkatkan pengetahuan yang dimiliki petani. Menurut Notoatmojo (2003) informasi yang diperoleh dari berbagai sumber akan mempengaruhi tingkat pengetahuan seseorang. Seseorang banyak memperoleh informasi maka akan cenderung mempunyai pengetahuan yang luas. Jumlah informasi dan sumber informasi yang diproleh petani ditampilkan Tabel 11 .

Tabel 11 menunjukkan bahwa sumber informasi seputar budidaya tanaman karet yang terdiri dari subsistem hulu, subsistem budidaya, subsistem hilir dan subsistem penunjang memiliki skor 1,97 atau dengan kategori cukup efektif. Artinya, sumber informasi yang dimiliki petani dilihat dari jenis informasi dan dan jumlah komunikatornya sudah cukup tinggi. Hal tersebut disebabkan karena antuasias dan semangat petani untuk mencari tahu berbagai macam informasi mengenai usahatani karet. Petani beranggapan bahwa tanaman karet merupakan sember pencaharian petani untuk dapat membahagiakan keluarga, sehingga petani harus merawat dan menjaga karet dengan baik.

Indikator jenis informasi memperoleh skor 2,08 atau termasuk ke dalam kategori cukup efektif. Artinya, pengetahuan yang dimiliki petani tentang usahatani karet sudah cukup baik. Pengetahuan yang baik tentang budidaya karet ini banyak didapatkan dari sekolah pelatihan untuk petani di Kecamatan Gunung Toar pada tahun 2017 lalu. Mulai dari sarana produksi seperti pupuk, bibit kemudian budidaya pada tanaman karet seperti pengolahan lahan, bibit, pemupukan, penyakit panen hingga cara mendapatkan harga yang baik disampaikan di dalam pelatihan tersebut.

Tabel 11. Karakteristik Eksternal: Sumber Informasi

\begin{tabular}{ccccccc}
\hline No & Sumber Informasi & Skor & Jiwa & $\%$ & Skor & Kategori \\
\hline 1 & Informasi & 1 & 20 & 24 & 2,08 & Cukup Efektif \\
& & 2 & 36 & 43 & & \\
\multirow{2}{*}{2} & Sumber & 3 & 27 & 33 & & \\
& 1 & 29 & 35 & 1,86 & Cukup Efektif \\
& 2 & 37 & 45 & & \\
\hline \multicolumn{2}{l}{ Rata-rata } & 17 & 20 & & Cukup Efektif \\
\hline
\end{tabular}

Sumber: Data diolah, 2019 
Hasil dari pelatihan tersebut yaitu banyak petani yang berminat untuk bergabung ke dalam kelompok tani dan menerapkan pemasaran karet dengan sistem lelang.

Indikator jumlah sumber informasi memperoleh skor 1,86 atau termasuk ke dalam kategori cukup efektif. Artinya, sumber informasi yang dimiliki petani sudah cukup banyak. Salah satu sumber informasi tersebut adalah dari dinas yang memberikan pelatihan kepada petani karet. Tidak hanya dari pelatihan, petani memiliki pengetahuan yang cukup baik tentang budidaya karet namun petani juga mendapatkannya dari petani lain yang mau membagikan pengalamannya dari pelatihan-pelatihan di luar daerah seperti di Pekanbaru. Sumber informasi yang terpenting lainnya yaitu dari penyuluh yang sangat aktif dalam hal tanaman karet. Salah satu penyuluh dari Dinas Perkebunan Kuantan Singingi mengatakan bahwa beliau adalah panyuluh yang paling aktif di Kuantan Singingi dalam hal tanaman karet. Pedagang dan pekerja pabrik karet juga menjadi salah satu sumber informasi bagi petani dalam menginformasikan harga karet, pupuk, pestisida, stimulan, koagulan dan sarana produksi lainnya.

\section{Unsur-Unsur Komunikasi}

Unsur-unsur komunikasi merupakan komponen-komponen terbentuknya suatu komunikasi. Suatu komunikasi yang baik tidak akan terjadi apabila tidak terdapat satu di antara komponen-komponen komunikasi. Unsur komunikasi terdiri atas sumber informasi, pesan / informasi, media, penerima, umpan balik / feedback dan lingkungan. Berikut ditampilkan tabel unsur-unsur komunikasi pada petani karet pola swadaya di Kecamatan Gunung Toar.

\section{Sumber Komunikasi}

Sumber komunikasi atau komunkator merupakan individu atau kelompok yang berperan menyampaikan informasi. Komunikasi pada petani karet di Kecamatan Gunung Toar yang berperan sebagai komunikator yaitu, penyuluh, pengurus inti "ketua, sekretaris dan bendahara" kelompok tani atau GAPOKTAN, teman-teman sesama petani, taoke, perangkat desa, pedagang, internet, dan media sosial.

Secara umum sumber informasi bagi petani tentang subsistem hulu, on-farm, penunjang dan hilir terkhususnya penjualan lateks adalah penyuluh, ketua GAPOKTAN ataupun kelompok tani. Beberapa informasi mengenai subsistem hulu juga didapat dari pedagang. Informasi mengenai bantuan pemerintah komunikator utama bagi petani adalah ketua kelompok tani.

Tabel 12. Unsur-Unsur Komunikasi

\begin{tabular}{|c|c|c|}
\hline No & Komponen & Keterangan \\
\hline 1 & Sumber Informasi & $\begin{array}{l}\text { Penyuluh, pengurus inti kelompok tani/ GAPOKTAN, petani lain, touke, } \\
\text { perangkat desa, pedagang, internet dan media social }\end{array}$ \\
\hline 2 & Pesan/ Informasi & $\begin{array}{l}\text { Subsistem hulu: bibit/ benih, pupuk, perangsang lateks, pestisida, koagulan } \\
\text { dan peralatan sadap. Subsistem budidaya: pembukaan lahan, seleksi bibit, } \\
\text { jarak tanam, penanaman bibit, perawatan tanaman menghasilkan, } \\
\text { pemupukan, teknik sadap, pengumpulan lateks dan penggunaan stimulan. } \\
\text { Subsistem hilir: penjualan lateks, penyimpanan dan pengolahan. Subsistem } \\
\text { penunjang: tempat peminjaman, koperasi dan kelompok tani }\end{array}$ \\
\hline 3 & Media & Brosur, media sosial whatsapp, handphone. \\
\hline 4 & Penerima & $\begin{array}{l}\text { Petani karet pola swadaya di Kecamatan Gunung Toar Kabupaten Kuantan } \\
\text { Singingi. }\end{array}$ \\
\hline 5 & Umpan Balik/ Feedback & Feedback setuju, Feedback siap mencoba dan Feedback penolakan. \\
\hline 6 & Lingkungan & $\begin{array}{l}\text { Fisik: kantor desa, kantor kecamatan, rumah kepala desa, tempat } \\
\text { perkumpulan petani seperti tempat pelelangan dan penimbangan serta di } \\
\text { kebun petani masing-masing. Sosial budaya: pertemuan-pertemuan anggota } \\
\text { kelompok tani prioritas diwakilkan oleh kaum laki-laki. }\end{array}$ \\
\hline
\end{tabular}

Sumber: Data diolah, 2019 


\section{Pesan}

Pesan atau informasi yang diperoleh petani secara keseluruhan telah didapatkan oleh petani keculai mengenai pengolahan lateks. Informasi yang dimaksud penelitian ini terdiri dari empat subsistem yaitu subsistem hulu, budidaya, hilir dan penunjang. Informasi mengenai subsistem hulu berupa jenis-jenis sarana produksi yang memiliki kualitas baik. Subsistem hulu merupakan ujung tombak kehidupan perkebunan beberapa tahun ke depan. Informasi mengenai subsistem hulu yaitu informasi tentang bibit/ benih, pupuk, perangsang lateks, pestisida, koagulan dan peralatan sadap karet, sehingga perlu dipastikan pengetahuan petani mengenai sarana produksi yang akan dibahas pada efek kognitif petani di Kecamatan Gunung Toar. Informasi mengenai subsistem budidaya yaitu informasi seputar teknik budidaya tanaman karet agar memberikan hasil produksi yang maksimal. Informasi tersebut berupa informasi pembukaan lahan, seleksi bibit, jarak tanam, penanaman bibit, perawatan tanaman menghasilkan, pemupukan, teknik sadap, pengumpulan lateks dan penggunaan stimulan. Beberapa petani telah menyadari bahwa hasil produksi tanaman karet tidak hanya tergantung dari luas lahannya, namun juga bergantung pada teknik budidaya yang diterapkan petani. Informasi mengenai subsistem hilir yaitu kegiatan yang dilakukan petani pasca panen seperti penjualan lateks, penyimpanan dan pengolahan. Informasi mengenai pengolahan karet tidak didapatkan petani karena tidak ada sumber informasi yang memberikan informasi mengenai pengolahan karet pasca panen. Informasi mengenai subsistem penunjang yang berisi informasi mengenai tempat peminjaman, koperasi dan kelompok tani.

\section{Media}

Saluran komunikasi atau media petani berkomunikasi seputar usahatani tanaman karet berupa pertemuan atau diskusi secara langsung baik antara petani dengan penyuluh ataupun petani dengan petani lain. Pertemuan atau diskusi biasanya hanya dilakukan oleh petani yang tergabung ke dalam kelompok tani, sedangkan petani yang tidak tergabung ke dalam kelompok tani media yang digunakan adalah tatap muka langsung dengan orang yang diperkirakan memiliki informasi yang dibutuhkan. Beberapa media yang juga digunakan adalah sosial media seperti whatsapp (aplikasi smartphone). Media berupa whatsapp mayoritas digunakan oleh petani yang berpendidikan paling rendah SMA. Saat wawancara yang peneliti lakukan belum ada responden yang berpendidikan SMP menggunakan whatsapp sebagai media komunikasi petani, namun handphone mayoritas digunakan petani sebagai media informasi petani seputar usahatani tanaman karet. Media berupa brosur juga pernah digunakan ketika dinas perkebunan beserta penyuluh hadir untuk memberikan penyuluhan.

\section{Penerima}

Penerima informasi atau komunikan adalah seseorang yang menjadi sasaran atau harapan komunikator untuk menerima informasi yang diberikan melalui suatu media. Penelitian efektivitas komunikasi ini menunjukkan bahwa yang berperan sebagai penerima komunikasi adalah petani karet pola swadaya di Kecamatan Gunung Toar Kabupaten Kuantan Singingi. Peran petani tersebut bisa sebagai kepala desa, touke karet, pemuka agama, ketua pemuda maupun tokoh masyarakat.

\section{Umpan Balik (Feedback)}

Umpan balik adalah respon yang diberikan oleh komunikan atau penerima pesan ketika informasi atau pesan telah disampaikan oleh komunikator atau sumber informasi. Respon dapat berupa sebuah perubahan perasaan ataupun perubahan tindakan yang dilakukan komunikan. Feedback yang diberikan oleh komunikan berupa feedback setuju atau sesuai dengan harapan ditunjukkan dengan kalimatkalimat setuju ataupun diam menyimak. Feedback siap untuk mencoba ditunjukkan dengan pertanyaan-pertanyaan teknis pelaksanaan. Feedback penolakan ditunjukkan dengan kalimat-kalimat perbandingan terhadap objek yang sama pada peristiwa yang berbeda.

\section{Lingkungan}

Lingkungan atau situasi komunikasi adalah segala sesuatu yang menjadi faktor penghambat atau pendorong dalam memengaruhi suatu komunikasi. Faktor lingkungan pada penelitian ini terdiri dari dua faktor yaitu lingkungan fisik, sosial budaya dan dimensi waktu. Lingkungan fisik komunikasi penelitian ini yaitu 
penyuluhan dilaksanakan di kantor desa, kantor camat, rumah kepala desa ataupun langsung turun ke lapangan yaitu penyuluh menemui petani ke tempat-tempat perkumpulan petani seperti tempat pelelangan atau penimbangan dan juga menemui satu persatu petani. Sosial budaya komunikasi penelitian ini yaitu kegiatan penyuluhan ataupun pertemuan-pertemuan anggota kelompok tani diwakilkan oleh kepala rumah tangga namun jika kepala rumah tangga berhalangan maka diwakilkan oleh anak lakilaki atau istrinya. Dimensi waktu komunikasi pada penelitian ini yaitu penyuluhan dilaksanakan satu kali seminggi dan terkadang satu kali dalam dua minggu jika kondisi cuaca tidak mendukung.

\section{KESIMPULAN DAN SARAN}

Karakteristik internal yang dimiliki petani karet di Kecamatan Gunung Toar yaitu: 99\% responden berusia produktif, $89 \%$ reesponden berjenis kelamin laki-laki, $42 \%$ berpendidikan responden SMA dan S1, $77 \%$ responden memiliki luas lahan sedang $(0,5-2 \mathrm{ha}), 71 \%$ memiliki pengalaman usahatani antara 11-20 tahun, $58 \%$ responden memiliki jumlah tanggungan antara 3-4 orang, tingkat kosmopolitan petani karet dinilai tidak efektif. Karakteristik eksternal yang dimiliki petani karet di Kecamatan Gunung Toar yaitu: Intensitas penyuluhan karet dinilai cukup efektif, ketepatan saluran penyuluhan dinilai cukup efektif, sumber informasi dinilai cukup efektif. Unsur-unsur komunikasi yang terjadi pada petani karet di Kecamatan Gunung Toar yaitu: (1) Sumber informasi yaitu: penyuluh, pengurus inti kelompok tani atau GAPOKTAN, teman-teman sesama petani, touke, perangkat desa, pedagang internet dan media sosial berupa whatsapp. (2) Pesan yang diperoleh terdiri dari: informasi tentang usahatani pada subsistem hulu, subsistem budidaya, subsistem hilir dan subsistem penunjang. (3) Media yang digunakan terdiri dari: pertemuan atau diskusi, smartphone berupa whatsapp, handphone dan brosur. (4) Penerima atau sasaran komunikasi adalah petani karet. (5) Feedback/umpan balik berupa feedback setuju, feedback siap mencoba dan feedback penolakan.(6) Unsur lingkungan yang digunakan terdiri dari lingkungan fisik yaitu di kantor desa, kantor camat, rumah kepala desa ataupun di lapangan langsung.
Sosial budaya yaitu pertemuan kelompok lebih diutamakan oleh kaum laki-laki. Dimensi waktu yaitu penyuluhan dilaksanakan satu kali seminggu.

Penyuluh secara aktif perlu memberikan penyuluhan kepada petani karet secara merata dan bisa bekerja sama bersama dengan dinasdinas terkait usahatani karet untuk memberikan pelatihan terhadap petani karet guna meningkatkan kosmopolitan petani karet pola swadaya di Kecamatan Gunung Toar.

\section{DAFTAR PUSTAKA}

Ahmadi, A. 2007. Psikologi Sosial. Jakarta: Rineka Cipta.

Association of Natural Rubber Producing Countries (ANRPC). (2018/10/12). Data natural rubber trends \& statistics. Retrieved from http://www.anrpc.org.

Badan Pusat Statistik Provinsi Riau. 2018. Provinsi Riau dalam angka 2018. Riau.

Budiyanto, G. 2014. Manajemen Sumber Daya Lahan. Yogyakarta: LP3M UMY.

Harahap, N.H.P., dan Bhima, A.S. 2018. Analisis Daya Saing Komoditas Karet Alam Indonesia ke Pasar Global. Jurnal Transborder, 1(2), 130- 143.

Husein, U. 2011. Metode Penelitian untuk Skripsi dan Tesis Bisnis. Cetakan ke 11. Jakarta: Rajawali Press.

Mardani, T.M., dan Nur, H.S. 2017. Analisis Usahatani Tanaman Pangan Jagung Di Kecamatan Juli Kabupaten Bireuen. Jurnal S. Pertanian, 1 (3), 203 - 204.

Mubarak, W.I., Chayatin, N., Rozikin, K., dan Supradi. 2007. Promosi Kesehatan Sebuah Pengantar Proses Belajar Mengajar dalam Pendidikan. Yogyakarta: Graha Ilmu.

Notoatmodjo, S. 2003. Pendidikan dan Perilaku Kesehatan. Jakarta: Rineka Cipta.

Permana, A.B. 2012. Analisis Tingkat Kesehatan Bank Berdasarkan Metode CAMELS dan Metode RGEC. Skripsi. 
Universitas Negeri Surabaya. Surabaya.

Rohi. 2008. Efektivitas Komunikasi Pemuka Pendapat Kelompok Tani dalam Menggunakan Teknologi Usahatani Padi. Tesis. Institut Pertanian Bogor. Bogor.

Rukka, H. 2003. Motivasi Petani dalam Menerapkan Usahatani Organik Padi Sawah. Tesis. Sekolah Tinggi Pasca Sarjana IPB. Bogor.

Simanjuntak, E.K.P. 2016. Analisis Penyuluhan dan Keberdayaan Petani Karet Pola Swadaya Di Kecamatan Tanah Putih
Kabupaten Rokan Hilir. Skripsi. Universitas Riau. Pekanbaru.

Sugiyono. 2005. Metode Penelitian Administrasi. Bandung: Alfabeta

Sutarno, N.S. 2006. Manajemen Perpustakaan suatu Pendekatan Praktik. Jakarta: Sagung Seto.

Triyanto, A. 2009. Organizational Citizenship Behavior (OCB) dan Pengaruhnya terhadap Keinginan Keluar dan Kepuasan Kerja Karyawan. Jurnal Manajemen, 7(4), 1- 13. 